\title{
\begin{tabular}{l|cc} 
Media & p-ISSN $1979-3693$ & e-ISSN 2477 - 0647 \\
Statistika & MEDIA STATISTIKA 12(2) 2019: 140-151 \\
http://ejournal.undip.ac.id/index.php/media_statistika
\end{tabular}
}

\section{PEMODELAN KEMISKINAN DI JAWA MENGGUNAKAN BAYESIAN SPASIAL PROBIT PENDEKATAN INTEGRATED NESTED LAPLACE APPROXIMATION (INLA)}

\author{
Retsi Firda Maulina', Anik Djuraidah ${ }^{2}$, Anang Kurnia ${ }^{2}$ \\ ${ }^{1}$ Badan Pusat Statistik \\ ${ }^{2}$ Departemen Statistika FMIPA, IPB \\ e-mail: retsi.firda@gmail.com
}

\section{DOI: 10.14710/medstat.12.2.140-151}

\section{Article Info:}

Received: 18 September 2019 Accepted: 21 December 2019 Available Online: 30 December 2019

Keywords:

Bayesian, INLA, Poverty, Probit, Spatial

\begin{abstract}
Poverty is a complex and multidimensional problem so that it becomes a development priority. Applications of poverty modeling in discrete data are still few and applications of the Bayesian paradigm are also still few. The Bayes Method is a parameter estimation method that utilizes initial information (prior) and sample information so that it can provide predictions that have a higher accuracy than the classical methods. Bayes inference using INLA approach provides faster computation than MCMC and possible uses large data sets. This study aims to model Javanese poverty using the Bayesian Spatial Probit with the INLA approach with three weighting matrices, namely K-Nearest Neighbor (KNN), Inverse Distance, and Exponential Distance. Furthermore, the result showed poverty analysis in Java based on the best model is using Bayesian SAR Probit INLA with KNN weighting matrix produced the highest level of classification accuracy, with specificity is $85.45 \%$, sensitivity is $93.75 \%$, and accuracy is $89.92 \%$.
\end{abstract}

\section{PENDAHULUAN}

Kemiskinan merupakan masalah yang kompleks dan bersifat multidimensional sehingga menjadi prioritas pembangunan (Vijaya, 2014). Upaya yang dilakukan untuk mendeteksi masalah kemiskinan adalah dengan menentukan model dan metode yang dapat mengidentifikasi faktor-faktor yang berpengaruh terhadap kemiskinan. Namun, aspek kemiskinan bukan hanya dipengaruhi oleh peubah-peubah penjelas saja, tetapi juga dipengaruhi oleh efek spasial (Zhou dan Liu, 2019). Kebijakan pemerintah dalam penanggulangan kemiskinan dengan analisis spasial dapat dilakukan dengan lebih komprehensif karena memperhatikan keadaan "tetangga" dari wilayah tersebut (Rahmawati et al., 2015).

Metode ekonometrik spasial semakin banyak digunakan dalam penelitian terapan di bidang pertanian, ekonomi, lingkungan, dan pembangunan. Namun, aplikasi metode ekonometrik spasial pada data diskret masih sedikit dan penerapan pada paradigma 
Bayesian juga masih sangat sedikit (Holloway et al., 2002). Pada penelitian lain, model probit konvensional yang digunakan untuk menganalisis peubah respon biner tanpa melihat faktor kebertetanggaan menjadikan keputusan menjadi tidak realistis, sehingga mungkin perlu untuk memasukkan efek spasial dalam model (LeSage et al., 2011).

Metode Bayes merupakan metode pendugaan parameter yang memanfaatkan informasi awal dan informasi contoh sehingga dapat memberikan dugaan yang memiliki ketepatan lebih tinggi dibandingkan dengan metode-metode klasik seperti metode kuadrat terkecil atau metode kemungkinan maksimum (Gill, 2002). Pendekatan Bayes umumnya digunakan pada model yang rumit/kompleks seperti pada aplikasi penelitian spasial (Anselin, 1988). Keuntungan utama pendekatan Bayes terletak pada pertimbangan kemampuannya dalam estimasi parameter melalui sebaran peluang posterior (Blangiardo et al., 2015).

LeSage dan Pace (2011) melakukan penelitian menggunakan model Bayesian SAR probit pendekatan simulasi intensif Markov Chain Monte Carlo (MCMC). Selanjutnya, Rue et al. (2009) mengemukakan metode Integrated Nested Laplace Approximation (INLA) untuk mendapatkan penduga posterior marjinal parameter. Bivand et al. (2014) menggunakam inferensi Bayes pendekatan INLA yang memberikan komputasi lebih cepat dibanding MCMC dan memungkinkan untuk data yang besar.

Data Badan Pusat Statistik (BPS) tahun 2017 mencatat jumlah penduduk miskin di Jawa sebesar 13.94 juta jiwa. Sementara jumlah penduduk miskin di Indonesia sebesar 26.58 juta jiwa. Hal ini berarti 52.43 persen penduduk miskin di Indonesia berada di Jawa padahal terdapat banyak kota-kota besar (metropolitan) seperti Jakarta dan Surabaya (Rachmawati et al. 2018). Fenomena inilah yang menjadikan penelitian mengenai kemiskinan di Jawa menarik untuk dilakukan.

Belum banyak penelitian yang mengkaji kemiskinan di Jawa dengan mempertimbangkan pengaruh spasial. Penggunaan model spasial pada data kemiskinan sangat dibutuhkan agar dapat diketahui pola hubungan antar wilayah. Oleh karena itu, penelitian ini bertujuan untuk memodelkan kemiskinan di Jawa menggunakan Bayesian Spasial Probit pendekatan INLA dengan tiga matriks pembobot, yaitu K-Nearest Neighbour (KNN), Inverse Distance, dan Exponential Distance. Selanjutnya melakukan pemetaan dan analisis kemiskinan di Jawa berdasarkan model terbaik.

\section{TINJAUAN PUSTAKA}

\subsection{Model Regresi Probit}

Salah satu model regresi yang digunakan untuk menganalisis peubah respon berskala nominal adalah regresi probit. Pemodelan regresi probit biner berasal dari peubah respon kualitatif $Y$ dengan model sebagai berikut:

$$
\begin{aligned}
& \Phi^{-1}(\mathbf{y})=\mathbf{X} \boldsymbol{\beta}+\boldsymbol{\varepsilon} \\
& \mathbf{y}=\Phi(\mathbf{X} \boldsymbol{\beta}+\boldsymbol{\varepsilon})
\end{aligned}
$$

Keterangan

y : vektor peubah respon ukuran nx1, dengan $y_{i}$ bernilai 0 atau 1

$\Phi$ : fungsi kumulatif distribusi normal, $\Phi(Z) \in[0,1]$

$\mathbf{X}$ : matriks peubah penjeas berukuran $\mathrm{nx}(\mathrm{k}+1)$

$\boldsymbol{\beta}$ : vektor koefisien parameter regresi yang berukuran $(\mathrm{k}+1) \mathrm{x} 1$

$\boldsymbol{\varepsilon} \quad$ : vektor galat berukuran $\mathrm{nx} 1$ 
Pada model probit, nilai $\mathbf{X} \boldsymbol{\beta}$ dianggap sebagai nilai $\mathrm{z}$ dalam sebaran normal, sehingga semakin tinggi nilai $\mathbf{X} \boldsymbol{\beta}$ maka suatu kejadian akan semakin mungkin terjadi. Interpretasi dalam persamaan regresi probit adalah ketika terjadi perubahan 1 satuan di $X_{i}$, maka Z-score dari y akan berubah sebesar $\hat{\beta}_{i}$.

\subsection{Model SAR (Spatial Autoregressive) Probit}

Pada model umum SAR, peubah respon (berskala kontinu) dimodelkan bergantung pada matriks W, ditambah dengan fungsi linier pada peubah penjelas dan galatnya (LeSage dan Pace, 2009). Kemudian, LeSage et al. (2011) menyediakan model SAR probit untuk mengestimasi peluang peubah respon $y_{i}$ yang bersifat biner (bernilai 0 atau 1). Model SAR probit adalah sebagai berikut:

$$
\begin{aligned}
& \mathbf{y}=\Phi\left((\mathbf{I}-\rho \mathbf{W})^{-1} \mathbf{X} \boldsymbol{\beta}+\boldsymbol{\varepsilon}^{*}\right) \\
& \Phi^{-1}(\mathbf{y})=(\mathbf{I}-\rho \mathbf{W})^{-1} \mathbf{X} \boldsymbol{\beta}+\boldsymbol{\varepsilon}^{*} \\
& \mathbf{y}^{*}=(\mathbf{I}-\rho \mathbf{W})^{-1} \mathbf{X} \boldsymbol{\beta}+\boldsymbol{\varepsilon}^{*}
\end{aligned}
$$

Keterangan

$$
\begin{array}{ll}
\mathbf{y} & \text { : vektor peubah respon ukuran } \mathrm{nx} 1 \\
\rho & \text { : koefisien parameter lag spasial } \\
\mathbf{W} & \text { : matriks pembobot spasial berukuran } \mathrm{nxn} \\
\mathbf{X} & \text { : matriks peubah penjelas berukuran } \mathrm{nx}(\mathrm{k}+1) \\
\boldsymbol{\beta} & \text { : vektor koefisien parameter regresi yang berukuran }(\mathrm{k}+1) \mathrm{x} 1 \\
\boldsymbol{\varepsilon}^{*} & \text { : vektor galat berukuran } \mathrm{nx} 1, \boldsymbol{\varepsilon}^{*} \sim N\left(\mathbf{0}, \sigma^{2}(\mathbf{I}-\rho \mathbf{W})^{-1}\left(\mathbf{I}-\rho \mathbf{W}^{t}\right)^{-1}\right)
\end{array}
$$

dengan $\mathbf{y}^{*} \sim T M V N\left\{(\mathbf{I}-\rho \mathbf{W})^{-1} \mathbf{X} \boldsymbol{\beta},\left[\sigma^{2}(\mathbf{I}-\rho \mathbf{W})^{-1}\left(\mathbf{I}-\rho \mathbf{W}^{t}\right)^{-1}\right]\right\}$. TMVN adalah sebaran Multivariate Truncated Normal. Interpretasi dalam model regresi SAR Probit adalah perubahan peubah penjelas pada matriks $X$ menyebabkan peluang terjadinya suatu kejadian juga akan berubah. Semakin tinggi nilai $\mathrm{X}$, maka suatu kejadian akan semakin mungkin terjadi.

\subsection{Integrated Nested Laplace Approximation (INLA)}

Rue et al. (2009) mengembangkan suatu metode untuk menghasilkan estimasi yang lebih akurat dan lebih cepat waktu komputasinya dibandingkan metode MCMC. Metode ini dinamai Integrated Nested Laplace Aproximation (INLA). Sesuai namanya metode ini menggunakan pendekatan Laplace.

Tujuan utama dari pendugaan Bayes adalah mencari sebaran posterior marjinal untuk setiap elemen dari vektor parameter yang dijabarkan sebagai berikut:

$$
p\left(\theta_{i} \mid \mathbf{y}\right)=\int p\left(\theta_{i}, \boldsymbol{\psi} \mid \mathbf{y}\right) d \boldsymbol{\psi}=\int p\left(\theta_{i} \mid \boldsymbol{\psi}, \mathbf{y}\right) p(\boldsymbol{\psi} \mid \mathbf{y}) d \boldsymbol{\psi}
$$

dan untuk setiap elemen dari vektor hiperparameter:

$$
p\left(\psi_{k} \mid \mathbf{y}\right)=\int p(\boldsymbol{\psi} \mid \mathbf{y}) d \boldsymbol{\Psi}_{-k}
$$

Langkah-langkah pendekatan Laplace untuk memperoleh sebaran posterior adalah (Blangiardo dan Cameletti, 2015):

1. Menghitung $p(\boldsymbol{\Psi} \mid \mathbf{y})$ melalui sebaran marjinal $p\left(\psi_{k} \mid \mathbf{y}\right)$ 


$$
\begin{gathered}
p(\boldsymbol{\Psi} \mid \mathbf{y})=\frac{p(\boldsymbol{\theta}, \boldsymbol{\Psi} \mid \mathbf{y})}{p(\boldsymbol{\theta} \mid \boldsymbol{\Psi}, \mathbf{y})} \\
\propto \frac{p(\mathbf{y} \mid \boldsymbol{\theta}, \boldsymbol{\Psi}) p(\boldsymbol{\theta} \mid \boldsymbol{\Psi}) p(\boldsymbol{\Psi})}{p(\boldsymbol{\theta} \mid \boldsymbol{\Psi}, \mathbf{y})} \\
\left.\approx \frac{p(\mathbf{y} \mid \boldsymbol{\theta}, \boldsymbol{\Psi}) p(\boldsymbol{\theta} \mid \boldsymbol{\Psi}) p(\boldsymbol{\Psi})}{\tilde{p}(\boldsymbol{\theta} \mid \boldsymbol{\Psi}, \mathbf{y})}\right|_{\boldsymbol{\theta}=\boldsymbol{\theta}^{*}(\boldsymbol{\Psi})} \\
=\tilde{p}(\boldsymbol{\Psi} \mid \mathbf{y})
\end{gathered}
$$

$\tilde{p}(\boldsymbol{\Psi} \mid \mathbf{y})$ merupakan penduga dari $p(\boldsymbol{\theta} \mid \boldsymbol{\Psi}, \mathbf{y})$

2. Menghitung $p\left(\theta_{i} \mid \boldsymbol{\Psi}, \mathbf{y}\right)$ untuk mendapatkan $p\left(\theta_{i} \mid \mathbf{y}\right)$.

Vektor parameter $\boldsymbol{\theta}=\left(\theta_{i}, \theta_{-i}\right)$ melalui pendekatan Laplace dapat dijabarkan:

$$
\begin{aligned}
& p\left(\theta_{i} \mid \boldsymbol{\Psi}, \mathbf{y}\right)=\frac{p\left(\left(\theta_{i}, \theta_{-i}\right) \mid \boldsymbol{\Psi}, \mathbf{y}\right)}{p\left(\theta_{-i} \mid \theta_{i}, \boldsymbol{\Psi}, \mathbf{y}\right)} \\
& \propto \frac{p(\boldsymbol{\theta} \mid \boldsymbol{\Psi}, \mathbf{y})}{p\left(\theta_{-i} \mid \theta_{i}, \boldsymbol{\Psi}, \mathbf{y}\right)} \\
& \left.\approx \frac{p(\boldsymbol{\theta} \mid \boldsymbol{\Psi}, \mathbf{y})}{\tilde{p}\left(\theta_{-i} \mid \theta_{i}, \boldsymbol{\Psi}, \mathbf{y}\right)}\right|_{\theta_{-i}=\theta^{*}{ }_{-i}\left(\theta_{i}, \boldsymbol{\Psi}\right)} \\
& =\tilde{p}\left(\theta_{i} \mid \boldsymbol{\Psi}, \mathbf{y}\right)
\end{aligned}
$$

$\tilde{p}\left(\theta_{-i} \mid \theta_{i}, \mathbf{\Psi}, \mathbf{y}\right)$ merupakan penduga Laplace dari $p\left(\theta_{-i} \mid \theta_{i}, \mathbf{\Psi}, \mathbf{y}\right)$

Setelah memperoleh $\tilde{p}(\boldsymbol{\Psi} \mid \mathbf{y})$ dan $\tilde{p}\left(\theta_{i} \mid \boldsymbol{\Psi}, \mathbf{y}\right)$, maka sebaran marjinal posterior dari $p\left(\theta_{i} \mid \mathbf{y}\right)$ dapat diduga melalui:

$$
\tilde{p}\left(\theta_{i} \mid \mathbf{y}\right) \approx \int \tilde{p}\left(\theta_{i} \mid \boldsymbol{\Psi}, \mathbf{y}\right) \tilde{p}(\boldsymbol{\Psi} \mid \mathbf{y}) d \mathbf{\psi}
$$

dimana bentuk integral dari persamaan di atas dapat diselesaikan dengan cara numerik melalui:

$$
\tilde{p}\left(\theta_{i} \mid \mathbf{y}\right) \approx \sum_{j} \tilde{p}\left(\theta_{i} \mid \boldsymbol{\Psi}^{(j)}, \mathbf{y}\right) \tilde{p}\left(\boldsymbol{\Psi}^{(j)} \mid \mathbf{y}\right) \Delta_{j}
$$

\section{METODE PENELITIAN}

\subsection{Data}

Data yang digunakan dalam penelitian ini merupakan data yang diperoleh dari publikasi Badan Pusat Statistik (BPS) tahun 2017. Unit amatan yang digunakan adalah kabupaten/kota. Peubah respon (Y) yang digunakan bersifat biner dengan mengelompokkan kabupaten/kota. Pengelompokan ini berdasarkan pada nilai Head Count Index (HCI) Indonesia tahun 2017. HCI adalah persentase penduduk yang berada di bawah garis kemiskinan. Suatu kabupaten/kota berstatus kemiskinan tinggi (diberi kode 1) jika nilai HCI lebih dari atau sama dengan HCI Indonesia dan berstatus kemiskinan rendah (diberi kode 0) jika nilai HCI kurang dari HCI Indonesia. Peubah bebas yang digunakan adalah laju pertumbuhan PDRB $\left(X_{1}\right)$, Persentase penduduk yang bekerja di sektor pertanian $\left(X_{2}\right)$, pengeluaran per kapita $\left(X_{3}\right)$, dan persentase penduduk 15 tahun ke atas yang tidak memiliki ijazah $\left(X_{4}\right)$. 
Pada dasarnya kemiskinan dipengaruhi oleh 4 faktor utama yaitu pertumbuhan ekonomi, ketenagakerjaan, standar hidup layak, dan pendidikan. Adapun pemilihan peubah bebas (X) pada penelitian ini merupakan representasi dari 4 faktor utama tersebut. Fosu (2009) menyatakan bahwa laju pertumbuhan PDRB (sebagai representasi dari faktor pertumbuhan ekonomi) adalah salah satu faktor yang berpengaruh terhadap tingkat kemiskinan. Menurut penelitian Gebremariam et al. (2006) terdapat hubungan simultan spasial antara tingkat bekerja dengan kemiskinan. Hubungan keduanya bersifat positif, artinya kesempatan kerja dapat mengurangi kemiskinan. Faktor ketenagakerjaan pada penelitian ini diwakili oleh peubah persentase penduduk yang bekerja di sektor pertanian. Wibowo (2019) menyatakan bahwa pendapatan per kapita merupakan acuan untuk menentukan tingkat kemiskinan yang terjadi. Pendapatan per kapita merupakan faktor standar hidup layak seseorang. Standar hidup layak dalam penelitian ini diwakili oleh peubah pengeluaran per kapita. Tilak (2010) menyatakan bahwa kemiskinan membuat orang yang berasal dari keluarga miskin tidak memiliki kesempatan untuk berpartisipasi sekolah meskipun pendidikan pada tingkat sekolah dasar (SD) telah diberikan secara gratis. Hal ini mengidikasikan bahwa faktor pendidikan erat kaitannya terhadap tingkat kemiskinan. Pada penelitian ini, faktor pendidikan diwakili oleh persentase penduduk 15 tahun ke atas yang tidak mempunyai ijazah.

\subsection{Metode Analisis Data} berikut:

Tahapan proses analisis data yan dilakukan pada penelitian ini adalah sebagai

1. Melakukan eksplorasi data HCI Jawa tahun 2017 secara deskriptif, kemudian membuat peta tematik penyebaran HCI di Jawa tahun 2017.

2. Melakukan pengklasifikasian kabupaten/kota menjadi kabupaten/kota kemiskinan tinggi dan kabupaten/kota kemiskinan rendah. Ketika nilai HCI suatu kabupaten/kota berada di atas nilai HCI Indonesia, maka peubah respon kabupaten/kota tersebut berkode 1 (kemiskinan tinggi), sementara ketika sebaliknya maka berkode 0 (kemiskinan rendah).

3. Menentukan model regresi probit berdasarkan peubah-peubah yang telah ditentukan. Secara umum, model regresi probit dapat dinyatakan sebagai berikut:

$$
\Phi^{-1}(y)=\beta_{0}+\beta_{1} X_{1}+\beta_{2} X_{2}+\beta_{3} X_{3}+\beta_{4} X_{4}+\varepsilon
$$

4. Menentukan matriks pembobot $W$. Matriks yang digunakan ada 3 jenis yaitu, matriks pembobot tetangga terdekat ( $k$-Nearest Neighbor Weights), kebalikan jarak (Inverse Distance), dan eksponensial jarak (Exponential Distance).

a. Matriks pembobot KNN:

i. Hitung jarak pusat antara unit ke- $i$ terhadap seluruh unit lainnya $j \neq i$.

ii. Beri peringkat sebagai berikut $d_{i j(1)} \leq d_{i j(2)} \leq \cdots \leq d_{i j(n-1)}$.

iii. Kemudian untuk setiap $k=1, \ldots, n-1$, atur $N_{k}(i)=\{j(1), j(2), \ldots j(k)\}$ yang berisi $k$ unit terdekat terhadap $i$.

iv. Untuk setiap $\mathrm{k}$, matriks pembobot $\mathrm{W}$ memiliki elemen $w_{i j}$ bernilai 1 jika daerah $\mathrm{i}$ berdekatan dengan daerah $\mathrm{j}$, sedangkan elemen diagonal utama akan selalu bernilai nol.

b. Matriks pembobot Inverse Distance:

i. Hitung jarak pusat antara unit ke- $i$ terhadap seluruh unit lainnya $j \neq i$, beri notasi $d_{i j}$

ii. Matriks pembobot $\mathrm{W}$ memiliki elemen $w_{i j}$, dimana $w_{i j}=d_{i j}{ }^{-1}$ 
c. Matriks pembobot dengan metode Exponential Distance:

i. Hitung jarak pusat antara unit ke- $i$ terhadap seluruh unit lainnya $j \neq i$, beri notasi $d_{i j}$

ii. Matriks pembobot $\mathrm{W}$ memiliki elemen $w_{i j}$, dimana $w_{i j}=\exp \left(-d_{i j}\right)$

5. Melihat ada atau tidaknya autokorelasi spasial pada peubah biner menggunakan Joint Count Statisctics (Lee dan Wong, 2000). Hipotesis yang diajukan adalah:

$$
\begin{aligned}
& H_{0}: O_{B W}=E_{B W} \text { (tidak ada autokorelasi spasial) } \\
& H_{1}: O_{B W} \neq E_{B W} \text { (ada autokorelasi spasial) }
\end{aligned}
$$

Dengan statistik uji sebagai berikut:

$$
Z_{\text {hitung }}=\frac{O_{B W}-E_{B W}}{\sigma_{B W}}
$$

$H_{0}$ akan ditolak jika nilai $\left|Z_{\text {hitung }}\right|>Z_{\frac{\alpha}{2}}$ dengan $\alpha$ merupakan taraf nyata sebesar 5 persen. $O_{B W}$ adalah banyaknya gabungan kabupaten/kota kemiskinan tinggi dan rendah dan $E_{B W}$ adalah nilai harapan gabungan kabupaten/kota kemiskinan tinggi dan rendah.

6. Menentukan model Bayesian SAR probit sebagai berikut:

$$
\Phi^{-1}(y)=y^{*}=\left(I_{n}-\rho W\right)^{-1}\left(\beta_{0}+\beta_{1} X_{1}+\beta_{2} X_{2}+\beta_{3} X_{3}+\beta_{4} X_{4}\right)+\varepsilon^{\prime}
$$

7. Menentukan prior masing-masing parameter dalam model SAR probit. LeSage dan Pace (2009) mengasumsikan sebaran prior saling bebas dengan ketentuan sebagai berikut:

i. $\beta \sim N(c, T)$

dengan $c=0$ dan $T$ merupakan nilai ragam yang besar yaitu $T=10^{10}$.

ii. $\quad \rho \sim U\left(\lambda_{\text {min }}^{-1}, \lambda_{\max }^{-1}\right)$

dengan $\lambda_{\text {min }}$ dan $\lambda_{\max }$ adalah nilai ciri (eigenvalue) minimum dan maksimum dari matriks bobot spasial $(W)$. Ketika $W$ sudah terstandardisasi baris maka $\lambda_{\max }=1$, sehingga nilai $\rho$ berada pada selang $(-1,1)$.

8. Menduga sebaran posterior parameter model menggunakan metode Integrated Laplace Aproximation (INLA). Penelitian ini menggunakan perangkat lunak $\mathrm{R}$ versi 3.5.1 dan package yang digunakan adalah R-INLA.

9. Menguji kebaikan model dengan melihat ketepatan klasifikasinya melalui nilai specifity sensitivity, dan accuracy. Jika peluang kurang dari 0.5 maka prediksi peubah respon $y=0$ dan jika peluang lebih dari 0.5 maka $y=1$.

\section{HASIL DAN PEMBAHASAN}

\subsection{Deskripsi Kemiskinan Kabupaten/Kota di Jawa}

Selama kurun waktu tiga tahun, jumlah penduduk miskin mengalami penurunan dari 28.59 juta jiwa di tahun 2015 menjadi 27.77 juta jiwa di tahun 2017. Namun, Jawa selalu menduduki peringkat pertama pulau yang memiliki jumlah penduduk miskin tertinggi di Indonesia. Tahun 2017, jumlah penduduk miskin di Jawa sebesar 14.79 juta jiwa yang artinya sebesar 53.25 persen penduduk miskin Indonesia berada di Jawa. Peta persentase penduduk miskin menurut kabupaten/kota di Jawa tahun 2017 disajikan pada Gambar 1. Wilayah yang berwarna merah menunjukkan kabupaten/kota tersebut memiliki persentase penduduk miskin yang tinggi sementara wilayah yang berwarna hijau menunjukkan kabupeten/kota memiliki persentase penduduk miskin yang rendah. Wilayah 
DKI Jakarta, Banten, dan Jawa Barat didominasi oleh warna hijau. Hal ini mengindikasikan bahwa kabupaten/kota di ketiga provinsi tersebut memiliki persentase penduduk miskin yang rendah. Sementara Jawa Timur memiliki memiliki warna yang cukup beragam ada yang hijau, kuning, sampai merah, artinya kabupaten/kota di Jawa Timur memiliki sebaran persentase penduduk miskin dengan rentang nilai terbesar. Lain halnya di Jawa Tengah dan DI Yogyakarta terdapat spot warna merah yang paling banyak diantara keempat provinsi lainnya. Hal ini menandakan bahwa provinsi Jawa Tengah dan DI Yogyakarta merupakan provinsi dengan persentase penduduk miskin tertinggi di Jawa.

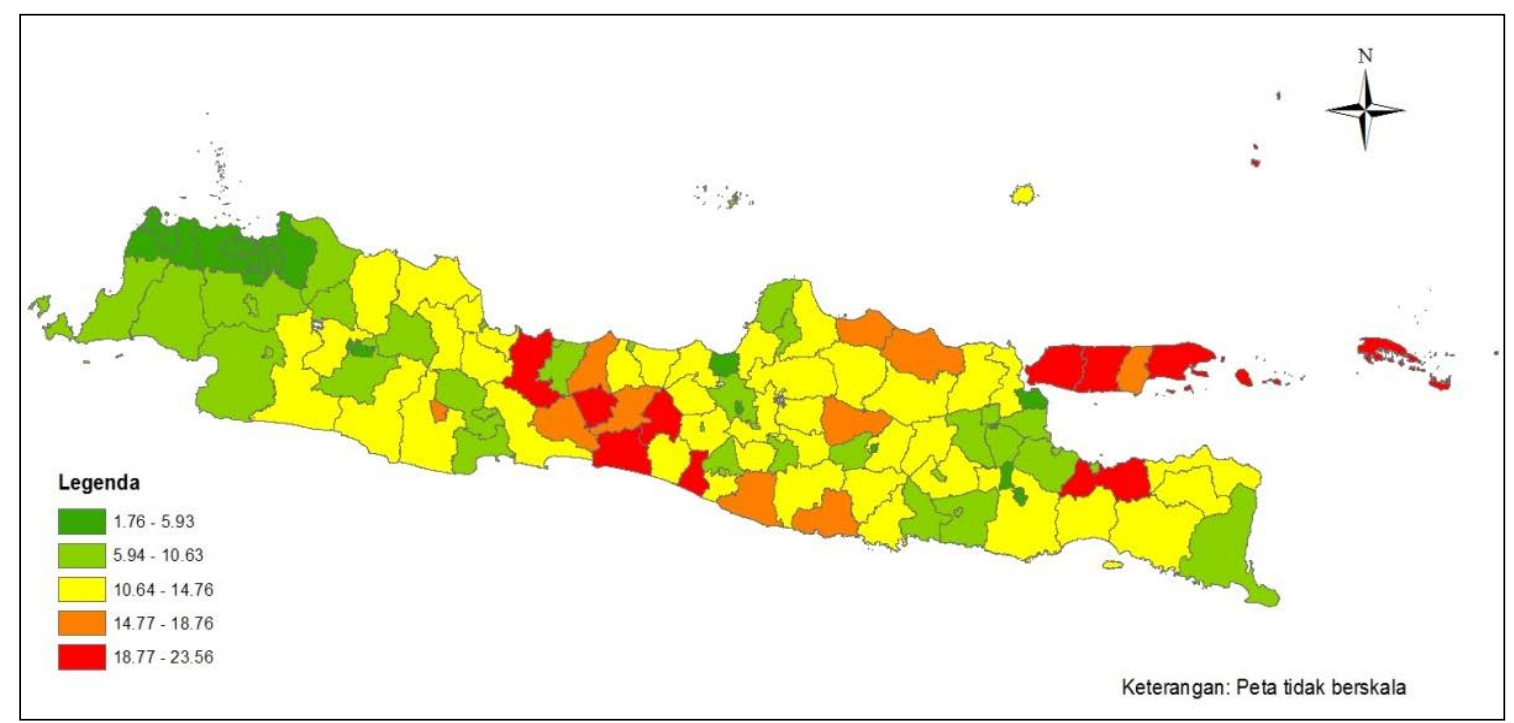

Gambar 1 Peta Persentase Penduduk Miskin Kabupaten/Kota di Jawa Tahun 2017 (Persen)

Penelitian ini fokus terhadap peubah respon biner, yaitu nilai 0 dan 1 . Oleh karenanya dilakukan pengelompokan kabupaten/kota menjadi kemiskinan tinggi dan kemiskinan rendah. Menurut data BPS, nilai HCI Indonesia tahun 2017 sebesar 10.64 persen. Ini berarti, 10.64 persen dari seluruh penduduk di Indonesia atau sekitar 26.58 juta jiwa adalah penduduk yang hidup di bawah garis kemiskinan. Dari 119 kabupaten/kota di Jawa, terdapat 64 kabupaten/kota dengan status kemiskinan tinggi dan 55 kabupaten/kota dengan status kemiskinan rendah. Rincian banyaknya kabupaten/kota menurut status kemiskinan ditunjukkan oleh Tabel 1.

Tabel 1 Status Kemiskinan Kabupaten/Kota Menurut Provinsi

\begin{tabular}{lrccc}
\hline \multirow{2}{*}{ Provinsi } & \multicolumn{2}{c}{ Status Kemiskinan Tinggi } & \multicolumn{2}{c}{ Status Kemiskinan Rendah } \\
\cline { 2 - 5 } & Jumlah & Persentase & Jumlah & Persentase \\
\hline DKI Jakarta & 1 & 0.84 & 5 & 4.20 \\
Banten & 0 & 0.00 & 8 & 6.72 \\
Jawa Barat & 11 & 9.24 & 16 & 13.45 \\
Jawa Timur & 24 & 20.17 & 14 & 11.76 \\
Jawa Tengah & 25 & 21.01 & 10 & 8.40 \\
DI Yogyakarta & 3 & 2.52 & 2 & 1.68
\end{tabular}


Jumlah 64 53.78 55 46.22

Sumber: Hasil Olah Data

\subsection{Dependensi Spasial}

Gambar 2 menunjukkan peta status kemiskinan kabupaten/kota di Jawa tahun 2017 yang telah dikelompokkan menjadi dua yaitu kemiskinan tinggi (berwarna merah) dan kemiskinan rendah (berwarna merah muda). Kabupaten/kota yang berwarna merah berdekatan dengan kabupaten/kota yang berwarna merah pula. Begitu pula kabupaten/kota yang berwarna merah muda berdekatan dengan kabupaten/kota yang berwarna merah muda. Hal ini mengindikasikan adanya autokorelasi spasial positif.

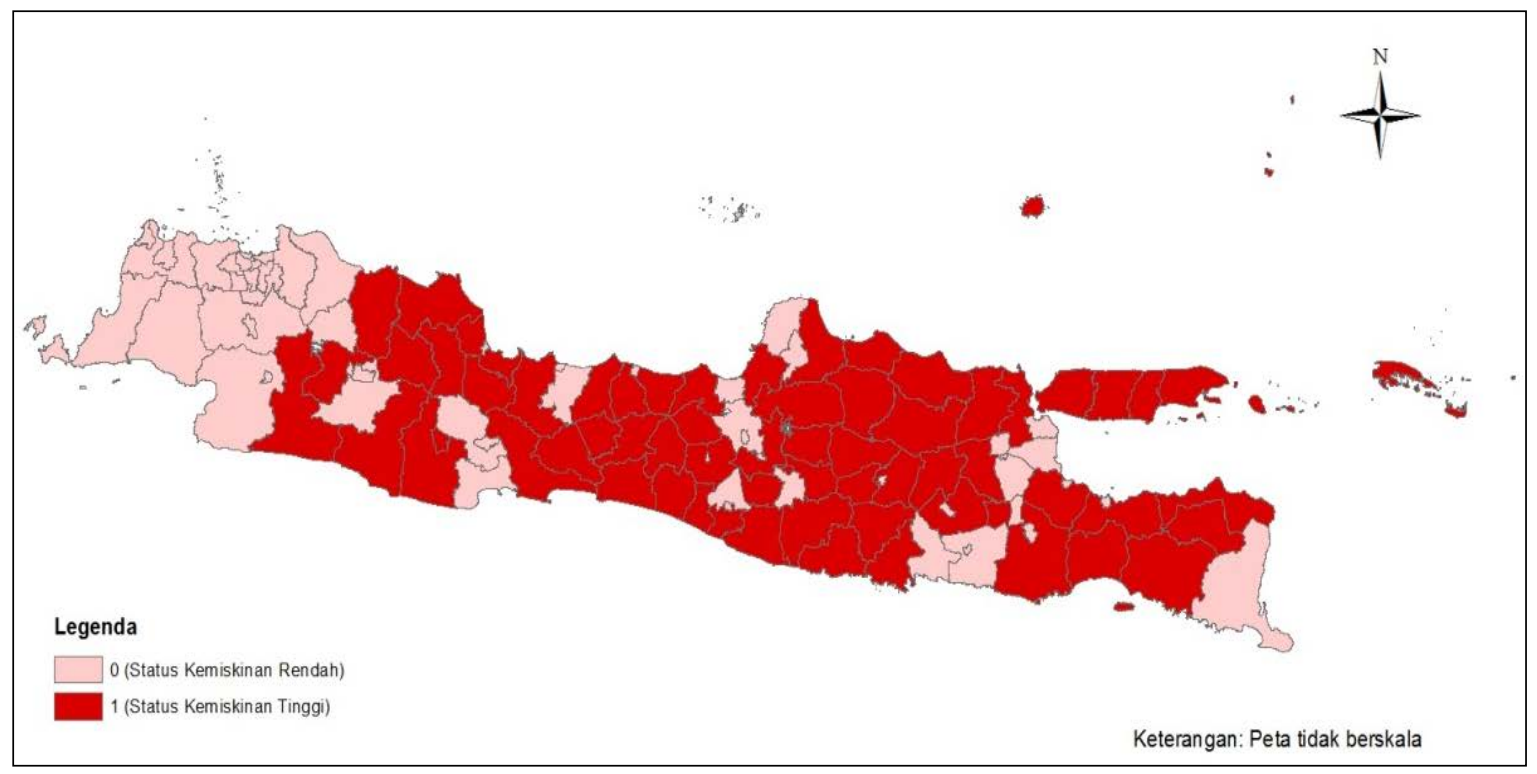

Gambar 2 Peta Status Kemiskinan Kabupaten/Kota di Jawa Tahun 2017

Tabel 3 menunjukkan hasil uji Joint Count Statistics menurut jenis matriks pembobot dengan hipotesis alternatif terdapat autokorelasi spasial positif. Hasil Joint Count Statistics untuk status kemiskinan kabupaten/kota di Jawa memiliki nilai-p kurang dari 0.05 pada semua jenis matriks pembobot. Hal ini menunjukkan bahwa terdapat autokorelasi spasial positif pada penyebaran status kemiskinan kabupaten/kota di Jawa pada taraf nyata 5 persen. Artinya status kemiskinan kabupaten/kota di Jawa bersifat mengelompok dan memiliki kesamaan pada lokasi yang berdekatan.

Tabel 3 Hasil uji Joint Count Statistics menurut jenis matriks pembobot

\begin{tabular}{lcc}
\hline \multicolumn{1}{c}{ Matriks Pembobot } & $P$-value (kode 0) & $P$-value (kode 1) \\
\hline KNN & $5,67 \times 10^{-8}$ & $1,50 \times 10^{-2}$ \\
Inverse Distance & $2,19 \times 10^{-8}$ & $3,00 \times 10^{-3}$ \\
Eksponensial Distance & $2,78 \times 10^{-13}$ & $1,42 \times 10^{-10}$ \\
\hline
\end{tabular}

Sumber: Hasil Olah Data

\subsection{Pemodelan Status Kemiskinan Menggunakan Bayesian SAR Probit dengan INLA}


Tabel 4 adalah rincian nilai penduga parameter untuk model Bayesian SAR probit dengan pendekatan INLA menggunakan tiga macam pembobot spasial. Nampak bahwa setiap pembobot spasial menghasilkan besaran pendugaan parameter yang tidak jauh berbeda. Selain itu, tanda (positif atau negatif) pada masing-masing peubah sama untuk semua pembobot spasial.

Peubah yang memiliki tanda negatif antara lain adalah laju pertumbuhan PDRB dan pengeluaran per kapita. Artinya, ketika peubah tersebut meningkat 1 persen, maka Z-score dari status kemiskinan kabupaten/kota akan menurun. Sementara, peubah yang memiliki tanda positif adalah persentase penduduk miskin yang bekerja di sektor pertanian dan persentase penduduk 15 tahun ke atas yang tidak mempunyai ijazah. Artinya, ketika peubah tersebut meningkat 1 persen, maka Z-score dari status kemiskinan kabupaten/kota akan meningkat. Peubah $\rho$ memiliki tanda positif, ini sesuai dengan hasil uji joint count statistics. Pada uji tersebut, disimpulkan bahwa terdapat autokorelasi spasial positif pada penyebaran status kemiskinan kabupaten/kota di Jawa.

Tabel 4 Nilai Penduga Parameter dan Selang Kepercayaan Bayesian SAR Probit

\begin{tabular}{ccccccc}
\hline Peubah & \multicolumn{2}{c}{ KNN } & \multicolumn{2}{c}{ Inverse Distance } & \multicolumn{2}{c}{ Eksponensial Distance } \\
\cline { 2 - 7 } & $\begin{array}{c}\text { Penduga } \\
\text { parameter }\end{array}$ & $\begin{array}{c}\text { Selang } \\
\text { Kepercayaan }\end{array}$ & $\begin{array}{c}\text { Penduga } \\
\text { parameter }\end{array}$ & $\begin{array}{c}\text { Selang } \\
\text { Kepercayaan }\end{array}$ & $\begin{array}{c}\text { Penduga } \\
\text { parameter }\end{array}$ & $\begin{array}{c}\text { Selang } \\
\text { Kepercayaan }\end{array}$ \\
\hline$X_{1}$ & $-0,39^{*}$ & $(-1,16 ;-0.08)$ & $-0,30^{*}$ & $(-0,72 ;-0,07)$ & $-0,27^{*}$ & $(-0,69,-0,09)$ \\
$X_{2}$ & $0,04^{*}$ & $(0,01 ; 0.10)$ & $0,03^{*}$ & $(0,01 ; 0,05)$ & $0,03^{*}$ & $(0,01,0,05)$ \\
$\ln X_{3}$ & $-6,11^{*}$ & $(-15,61 ;-0.24)$ & $-4, .68^{*}$ & $(-9,31 ;-0,42)$ & $-4,57^{*}$ & $(-9,27,-0,17)$ \\
$X_{4}$ & $0,08^{*}$ & $(0,02 ; 0.19)$ & $0,06^{*}$ & $(0,02 ; 0,10)$ & $0,06^{*}$ & $(0,02,0,11)$ \\
$\rho$ & $0,16^{*}$ & $(0,01 ; 0.43)$ & $0,44^{*}$ & $(0,42 ; 0,45)$ & $0,19^{*}$ & $(0,14,0,24)$ \\
\hline
\end{tabular}

Keterangan *: Signifikan pada taraf 5 persen

\subsection{Kebaikan Model}

Tabel 5 menunjukkan persentase ketepatan klasifikasi berdasarkan tiga matriks pembobot. Berdasarkan nilai spesifisitas, sensitivitas, akurasi, dan banyaknya kabupaten/kota yang salah klasifikasi, maka model yang terbaik adalah model dengan matriks pembobot spasial KNN. Nilai spesifisitas, sensitivitas, dan akurasi pada matriks pembobot spasial KNN merupakan yang tertinggi dibandingkan matriks pembobot spasial lainnya. Begitu pula hasil ketepatan klasifikasinya, matriks pembobot spasial KNN menghasilkan kabupaten/kota dengan salah klasifikasi paling sedikit dibandingkan matriks pembobot spasial lainnya. 
Tabel 5 Persentase Ketepatan Klasifikasi Pada Tiga Matriks Pembobot

\begin{tabular}{|c|c|c|c|}
\hline \multirow[b]{2}{*}{ Persentase Ketepatan Klasifikasi } & \multicolumn{3}{|c|}{ Matriks Pembobot Spasial } \\
\hline & KNN & $\begin{array}{l}\text { Inverse } \\
\text { Distance }\end{array}$ & $\begin{array}{l}\text { Eksponensial } \\
\text { Distance }\end{array}$ \\
\hline Spesifisitas & $85,45 \%$ & $76,36 \%$ & $76,36 \%$ \\
\hline Sensitivitas & $93,75 \%$ & $87,50 \%$ & $89,06 \%$ \\
\hline Akurasi & $89,92 \%$ & $82,35 \%$ & $83,19 \%$ \\
\hline $\begin{array}{l}y=0 \text { tetapi } \hat{y}=1 \\
\text { (kemiskinan rendah tetapi terklasifikasi tinggi) }\end{array}$ & 8 & 13 & 13 \\
\hline $\begin{array}{l}y=1 \text { tetapi } \hat{y}=0 \\
\text { (kemiskinan tinggi tetapi terklasifikasi rendah) }\end{array}$ & 4 & 8 & 7 \\
\hline
\end{tabular}

Peta hasil prediksi status kemiskinan kabupaten/kota di Jawa menggunakan model Bayesian SAR Probit pendekatan INLA dengan matriks pembobot KNN ditunjukkan pada Gambar 3. Kabupaten/kota yang salah klasifikasi status kemiskinannya dapat diketahui melalui peta ini.

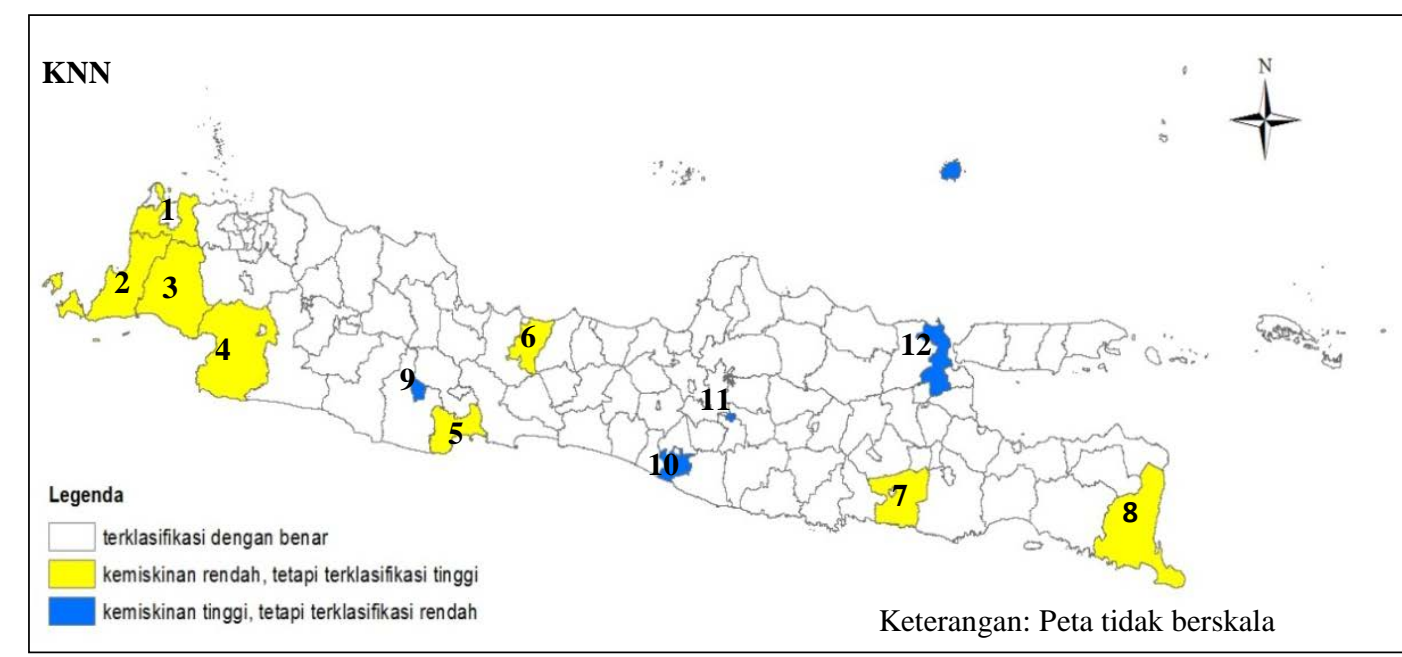

Keterangan:

$\begin{array}{llllll}1 & \text { Kab. Serang } & 5 & \text { Kab. Pangandaran } & 9 & \text { Kota Tasikmalaya } \\ 2 & \text { Kab. Pandeglang } & 6 & \text { Kab.Tegal } & 10 & \text { Kab. Bantul } \\ 3 & \text { Kab. Lebak } & 7 & \text { Kab. Blitar } & 11 & \text { Kota Surakarta } \\ 4 & \text { Kab. Sukabumi } & 8 & \text { Kab. Banyuwangi } & 12 & \text { Kab. Gresik }\end{array}$

Gambar 3 Peta Missclassification Kabupaten/Kota di Jawa dengan Matriks KNN

Berdasarkan kriteria-kriteria yang telah dijabarkan sebelumnya, maka dapat disimpulkan bahwa model terbaik adalah Bayesian SAR Probit pendekatan INLA dengan matriks pembobot KNN. Persamaan yang dihasilkan sesuai dengan Tabel 4 kolom kedua yaitu sebagai berikut:

$$
\Phi^{-1}(y)=y^{*}=\left(I_{n}-0.156 W\right)^{-1}\left(-0.391 X_{1}+0.043 X_{2}-6.111 \ln X_{3}+0.083 X_{4}\right)
$$

Pada Tabel 4, nampak bahwa keempat peubah bebas signifikan mempengaruhi status kemiskinan di Jawa dengan taraf nyata sebesar 5 persen.

Berdasarkan koefisien model probit dapat dilihat bahwa terdapat hubungan negatif antara laju pertumbuhan PDRB $\left(X_{1}\right)$ dengan status kemiskinan kabupaten/kota, sehingga semakin tinggi laju pertumbuhan PDRB, maka peluang suatu kabupaten/kota untuk 
memiliki status kemiskinan tinggi akan semakin menurun. Terdapat hubungan positif antara persentase penduduk yang bekerja di sektor pertanian $\left(X_{2}\right)$ dengan status kemiskinan kabupaten/kota, sehingga semakin tinggi persentase penduduk yang bekerja di sektor pertanian, maka peluang suatu kabupaten/kota untuk memiliki status kemiskinan tinggi akan semakin meningkat.

Hubungan pengeluaran per kapita $\left(X_{3}\right)$ terhadap status kemiskinan kabupaten/kota bernilai negatif. Artinya, semakin tinggi pengeluaran per kapita suatu kabupaten/kota, maka peluang kabupaten/kota tersebut untuk memiliki status kemiskinan tinggi akan semakin menurun. Terdapat hubungan positif antara persentase penduduk 15 tahun ke atas yang tidak mempunyai ijazah $\left(X_{4}\right)$ dengan status kemiskinan kabupaten/kota, sehingga semakin tinggi persentase penduduk 15 tahun ke atas yang tidak mempunyai ijazah, maka peluang suatu kabupaten/kota untuk memiliki status kemiskinan tinggi akan semakin meningkat.

Penduga $\rho$ memiliki hubungan positif, artinya dengan bertambahnya peluang suatu kabupaten/kota untuk memiliki status kemiskinan tinggi akan turut menambah peluang kabupaten/kota terdekatnya untuk memiliki status kemiskinan tinggi pula. Berdasarkan koefisien penduga parameter, pengeluaran per kapita merupakan peubah yang dapat menurunkan kemiskinan dengan peluang terbesar.

\section{KESIMPULAN}

Status kemiskinan di Jawa memiliki dependensi spasial positif, dengan kata lain, status kemiskinan antar kabupaten/kota di Jawa cenderung mengelompok. Status kemiskinan Jawa dipengaruhi oleh laju pertumbuhan PDRB, persentase penduduk yang bekerja di sektor pertanian, pengeluaran per kapita, dan persentase penduduk yang tidak memiliki ijazah. Pemodelan kemiskinan di Jawa menggunakan Bayesian SAR Probit INLA dengan matriks pembobot KNN merupakan model terbaik yang hanya menghasilkan 12 kabupaten/kota yang terklasifikasi salah status kemiskinannya dengan tingkat ketepatan klasifikasi yang tertinggi, dengan nilai spesifisitas $85.45 \%$, sensitivitas $93.75 \%$, dan akurasi $89.92 \%$.

\section{DAFTAR PUSTAKA}

Anselin, L. 1988. Spatial Econometrics: Methods and Models. Dordrecth: Kluwer Academic Publisher.

[BPS] Badan Pusat Statistik. 2017. Data dan Informasi Kemiskinan Kabupaten/Kota Tahun 2017. Jakarta: Badan Pusat Statistik.

Bivand, R. S., Rubio, V. G., dan Rue, H. 2014. Approximate Bayesian Inference for Spatial Econometrics Models. Spatial Statistics, doi:10.1016/j.spasta.2014.01.002.

Blangiardo, M. dan Cameletti, M. 2015. Spatial and Spatio-temporal Bayesian Models with R-INLA. Chichester: John Wiley \& Sons Ltd.

Fosu, A. K. 2009. Inequality and The Impact of Growth on Poverty: Comparative Evidence for sub-Saharan Africa. The Journal of Development Studies, Vol. 45, No. 5, hal. 726-745.

Gebremariam, G. H., Gebremedhin, T. G., dan Schaeffer, P. V. 2006. An Empirical Analysis of County-Level Determinants of Small Business Growth and Poverty in 
Appalachia: A Spatial Simultaneous-Equations Approach. Southern Agricultural Economics Association Annual Meeting, Orlando. Florida(AS).

Gill, J. 2002. Bayesian Methods: A Social and Sciences Approach. Chapman \& Hall/CRC Press Company.

Holloway, G., Shankar, B., dan Rahman, S. 2002. Bayesian Spatial Probit Estimation a Primer and an Application to HYV Rice Adoption. Agricultural Economics, Vol. 27, No. 3, hal. 383-402. doi: 10.1016/S0169-5150(02)00070-1.

Lee, J. dan Wong, S. D. 2001. Statistical Analysis with Arcview GIS. New York: John Willey \& Sons. Inc.

LeSage, J. P., Kelley, P., Lam, N., Campanella, R., dan Liu, X. 2011. New Orleans Business Recovery in The Aftermath of Hurricane Katrina. J. Roy Statist. Soc. Ser. A 174 Part 4, 1007-1027.

LeSage, J. P. dan Pace, R. K. 2009. Introduction to Spatial Econometrics. New York (USA): Taylor and Francis Group, LLC.

Rachmawati, R.N., Djuraidah, A., Fitrianto, A., dan Sumertajaya, I.M. 2018. SpatioTemporal Models using R-INLA with Generalized Extreme Value Ditribution in Hierarchical Bayes Regression. IJRSET, Vol. 4, Issue 4.

Rahmawati, R., Safitri, D., dan Fairuzdhiya, O. U. 2015. Analisis Spasial Pengaruh Tingkat Pengangguran terhadap Kemiskinan di Indonesia (Studi Kasus Provinsi Jawa Tengah). Media Statistika, Vol. 8, No. 1, hal. 23-30.

Rue, H., Martino, S., dan Chopin, N. 2009. Approximate Bayesian Inference for Latent Gaussian Model by Using Integrated Nested Laplace Approximations (with Discussion). Journal of Royal Statistical Society Series B. Vol. 71, hal. 319-392.

Tilak, J. B. G. 2010. Education and Poverty. Journal of Human Development: A MultiDisciplinary Journal for People-Centered Development. Vol. 3, No. 2, hal. 191207.

Vijaya, R. M., Latohi, R., dan Swaminathan, H. 2014. Moving from The Household to The Individual: Multidimensional Poverty Analysis. World development Vol. 59, hal. 70-81.

Wibowo, B. 2019. Dampak Spillover Kebijakan Fiskal terhadap Pencapaian Pertumbuhan Inklusif Antarprovinsi di Indonesia, Tesis Magister Ilmu Ekonomi Institut Pertanian Bogor.

Zhou, Y. dan Liu, Y. 2019. The Geography of Poverty: Review and Research Prospects. Journal of Rural Studies. 